\title{
The effect of using quarter individual milking system "MultiLactor" on improvement of milk performance and milk quality of different dairy cows breeds in different farms
}

\author{
Shehadeh Kaskous* \\ Department of Research and Development, Siliconform GmbH, Schelmengriesstrasse 1, D-86842 Türkheim/Allgäu, Germany
}

\section{A B S T R A C T}

\begin{abstract}
Milking machine is an important factor in milk performance and milk quality during the course of milk removal in dairy cows. The purpose of the present study was to determine the effect of using quarter individual milking system "MultiLactor" (ML) on improvement of milk performance and milk quality of different dairy cows breeds in different farms. A quarter individual Milking system ML has a single guided tubes with a vacuum of $34 \mathrm{kPa}$, pulsation rate of $60 \mathrm{cycle} / \mathrm{min}$ and ration of 60 to $40 \%$. The system has also a periodic air inlet and a sequential pulsation. In this study, milking data were collected from 170 Holstein Friesian cows (Farm 1), 130 Holstein Friesian (red) cows (Farm 2) and 54 Brown Swiss cows (Farm 3). Quantitative and qualitative milk data of these farms have been recorded by Association of milk records, Switzerland. The primary milking data of cows were collected during the period from 2010 to 2015 after using the new milking system. The data were later processed with Excel program and analyzed using the statistical analysis system (SAS). The results are presented as least square means with standard errors (LSM $\pm \mathrm{SE}$ ) and the significant difference was set at $(P<0.05)$. The daily milk yield during the study period from 2010 to 2015 increased significantly to $117 \%$ (from $34.64 \pm 1.23$ to $40.51 \pm 1.00 \mathrm{~kg} /$ day/animal), $162 \%$ (from $20.29 \pm 1.37$ to $30.88 \pm 0.65 \mathrm{~kg} / \mathrm{day} /$ animal) and $151 \%$ (from $15.04 \pm 0.83$ to $22.71 \pm 0.54 \mathrm{~kg} /$ day/animal) in farms 1,2 and 3 respectively after using of ML milking system. Fat and protein content of the milk also increased during the same period of three breeds and farms. However, the results showed that the milking system ML had significant effects on the udder health status by reducing continuously somatic cell count (SCC) in milk by $54.81 \%, 51.54 \%$ and $51.66 \%$ in farm 1,2 and 3 respectively during the study period. Furthermore, Lactation number of the cows were continuously increased in the study during the same period. In conclusion, after 5 years of using ML, it has been shown that a quarter individual milking machine was adapted to the physiological requirements of dairy farms and different breeds and the milk removal with ML brings better quantity and quality of milk in terms of improved milk performance, fat \%, protein $\%$ and lower number of SCC in the milk.
\end{abstract}

Key words: Breeds; Dairy farms; Milking machine; Milk quality; Milk yield; MultiLactor

\section{INTRODUCTION}

Milk yield and milk quality in dairy farms are affected by biological and management factors (Fahr and Lengerken, 2003; Annen et al., 2004; Marnet and Komara, 2008; Dufour et al., 2011; Assan, 2014; Cinar et al., 2015). Cattle breeders are not interested only in getting more milk, but also in having a better milk quality, which increase the basic rates of milk components especially fat and protein percentage and lower number of SCC in the milk (Petrovska and Jonkus, 2014). This interest leads to higher profit by production increase and at the same time more health benefits to the consumer of this milk.
Breed, age, nutrition, and health status of the cow are well known to influence milk yield and composition (Ontsouka et al., 2003; Cinar et al., 2015). However, different cattle breeds vary in average of milk yield and components (Fahr and Lengerken, 2003; Marnet \& Komara, 2008).

Milking machine is also considered an important factor in milk performance and milk quality during the course of milk removal in Dairy cows (Dang and Anand, 2007; Petrovska and Jonkus, 2014; Kaskous and Fadlelmoula, 2015; kaskous, 2016).

Fehlings (2006) reported after an investigation of 7000 Bavarian (Germany) farms that real problems with udder

\footnotetext{
${ }^{*}$ Corresponding author:

Shehadeh Kaskous, Department of Research and Development, Siliconform GmbH, Schelmengriesstrasse 1, D-86842 Türkheim /Allgäu, Germany, Tel.: +49-8245-614, Fax: +49-8245-3286, E-mail: skaskous@siliconform.com
}

Received: 04 June 2017; $\quad$ Accepted: 11 January 2018 
health and high SCC in the milk are often due to deficiencies in milking technology. $46.8 \%$ of them have problems with the milking machine. However, milking systems had defects in the constructive, technical or functional area. The new evaluation of udder health in Germany clearly shows that only $56 \%$ of the dairy cows in 2015 are classified as healthy (they have healthy udders and the SCC less than 100.000 cells/ml milk) (Behr, 2017).

It is equally important that the milking routine and hygiene must be optimal. It is possible to have a properly installed and well-functioning milking technique available in the farm and at the same time the cows are badly milked. An increase in milk yield and improvement of milk constituents after the application of a new milking machines is associated with the physiological adaptability of the dairy cows to the milking machines (Tancin et al., 2006; Sandrucci et al., 2007; Kaskous \& Fadlelmoula, 2015). Moreover, it has been reported that milk removal is optimal during milking time, when the cows are well prepared and the using milking machine is suitable for the dairy cows requirement (Kanswohl et al. 2012)

ML milking system was developed and practically used in the field few years ago. The practical results have shown that the using of ML in comparison with the conventional milking systems is more effective in term of positive stimulation effect (Müller et al., 2011). The new study clearly shows the positive influence of the ML milking system on milk yield and composition (kaskous, 2016). These results confirm the importance of the type of milking machine used in dairy farms.

Therefore, the aim of this study was to examine the effect of using ML milking system on the improvement of milk performance and milk composition of different breeds in different dairy farms. However, there are only limited data on the effect of milking technique on milk production and composition in the world.

\section{MATERIAL AND METHODS}

The study was carried out on different breeds in three known cattle farms in Switzerland. Hereby, the description of the farms was presented:

Farm 1: 170 Holstein-Friesian dairy cows were examined using of ML milking system from 2010 to 2015. At the beginning of the experiments, the average milk production was $10565 \mathrm{~kg}$ in $305 \mathrm{~d}$, the mean age was 56 months, the mean lactation number was 2.3 The cows were kept in loose housing and they were fed ad libitum with a partial mixed ration (grass-and corn-silage, hay) and received concentrate according to the production level. All dairy cows were milked three times a day at 5:00, 13:00 and 21:00 hours in a carousel milking parlor ( 24 places) with a ML milking system.

Farm 2: 130 Holstein-Friesian (Red) dairy cows were studied for the use of ML milking system over a period of 5 Years (from 2010 to 2015). At the beginning of experiments, the average milk production was $6188 \mathrm{~kg}$ in $305 \mathrm{~d}$, the mean age was 46 months, the mean lactation number was 1.8 The cows were kept in loose housing and were fed ad libitum with a partial mixed ration (grass-and corn-silage, sugar beet pulp, hay) and received concentrate according to the production level. The cows were milked twice daily at 6:00 and 17:00 hours using a tandem milking parlor (2X5) with ML milking system.

Farm 3: 54 Brown Swiss Dairy cows were studied for the use of ML milking system over a period of 4 Years (from 2011 to 2015).At the beginning of experiments, the average milk production was $4605 \mathrm{~kg}$ in $305 \mathrm{~d}$, the mean age was 39 months, the mean lactation number was 1.05. The cows were kept in loose housing and were fed according to their maintenance requirements and milk yield. The cow's ration was limited to the basic feed and minimum concentrate feed ( $2 \mathrm{~kg} /$ day/animal). The cows grazed a lot of grass directly on the pasture or in the stable as hay. The cows were milked twice a day at 6:00 and 17:00 hours in a tandem milking parlor (2x3) with ML milking system.

\section{Characteristics of the used milking technique}

ML is a well-handled and animal-friendly semi-automatic milking system that differs technically from conventional milking machine. It is based on a quarter-individual milking system. The system provides periodic air inlet into the teat cups (BioMilker). The working vacuum level was set to 34 $\mathrm{kPa}$ and sequential pulsation was adopted. The pulsation rate and ratio were 60 cycles/min and 65:35, respectively. In addition ML has very good cleaning system and provided with silicon liners.

\section{The milking routine}

At the time of milking with ML in the investigated Farms, the milking routine started with pre-milking preparations, which consisted of fore-stripping of one or two squirts of milk from each teat and cleaning the udder and teats. After that, the milking unit swing directly in front of the cow's udder. The teats cups were pulled out of the storing individually or in pairs and manually attached to the teats. Subsequent to this step, the system is started on the control display and the pre-stimulation began. The pre-stimulation is structured to be intensively activated with a normal pulse rate $(60 \mathrm{cycles} / \mathrm{min})$ and reduced the milking phase (b-phase) of $10 \%$ over a period of $50 \mathrm{~s}$. At the same time, intensive movement of the teats cups is regulated as an 
additional stimulation by an actuator. This is an arm on which four milk tubes lie. During the pre-stimulation and the milking time (main and post-milking), this arm moves up and down. This movement is transferred to the teats cups and vibrate the teats. When the milk flow reaches $250 \mathrm{~g} / \mathrm{min}$, then the milking process automatically ends with the detachment of the milking unit and each teat is dipped with a solution containing Chlorhexidin. At the same time teat cups are cleaned and disinfected automatically with water and per acetic acid solution $(0.5 \%)$ after each cow and milking.

\section{Recording of Milk yield and collection of milk samples and analysis}

Recording of milk yield and collection of $50 \mathrm{ml}$ bottle of milk sample were carried out monthly from each cow of the experimental farms and breeds during the study period. The milk samples are preserved by Bronopol and then, they sent to the laboratory. In the lab, milk samples are processed with modern devices. Fat, protein and lactose in the milk were determined by Infrared -spectroscopy and SCC in the milk was determined by fluorescence optical counting.

\section{Data collection and statistical analyses}

All milk data from the three praxis dairy farms were collected by milk recorded Association Switzerland over a period from 2010 to 2015 in farm 1 and 2 and from 2011 to 2015 in farm 3. The primary data were processed with Excel and evaluated using statistics program SAS (SAS. 1999). The data was checked for normal distribution and it was shown that the data was distributed normally. Then, the data were analyzed by ANOVA. Significant differences $(\mathrm{P}<0.05)$ of the milk parameters were localized by using Bonferroni's t test. The results are presented as least square means with standard errors (LSM \pm SE).

\section{THE RESULTS}

Figures 1 to 6 show the results of the development of milk yield, composition and lactation number of the studied farms after using the quarter individual milking system ML.

\section{Development of the daily Milk yield}

There was a significant increase in daily milk yield in Farm 1 (Holstein Frisian) in 2013 compared with milk yield after changeover in 2010. The values were at 38.15 \pm 1.27 in 2013 and $34.64 \pm 1.23 \mathrm{~kg}$ milk/day/animal in 2010 . This corresponds to an increase in the production rate to $110.13 \%$. After 2013 , the daily milk yield continued to increase and in 2015 it will reach approx. $40.51 \pm 1.00 \mathrm{~kg}$ milk/day/animal. This matches an increase in production up to $116.95 \%$ compared with 2010 as shown in Fig.1. Similar results were demonstrated in Farm 2 (Holstein Frisian/red) (Fig. 1) and the daily milk yield increased

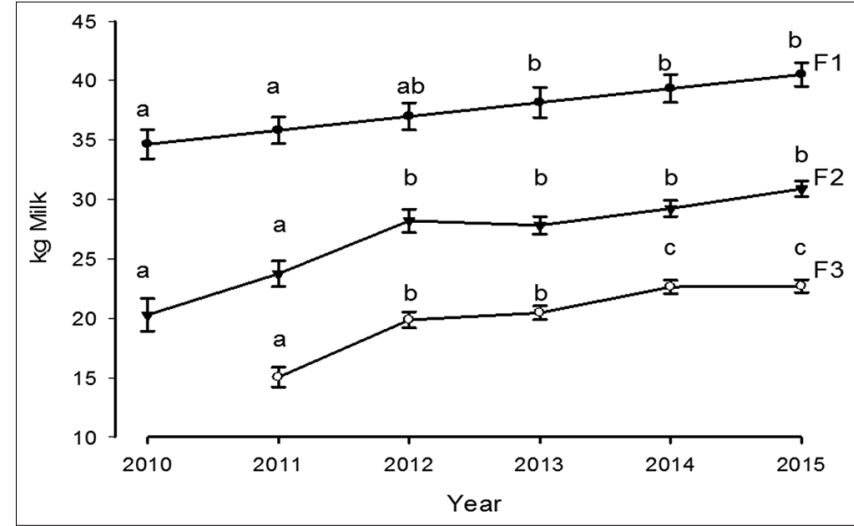

Fig 1. Development of daily milk yield after using of ML milking system in different breeds from different dairy farms. F1: Farm 1 (Holstein); F2: Farm 2 (Holstein/Red); F3: Farm 3 (Brown Swiss).

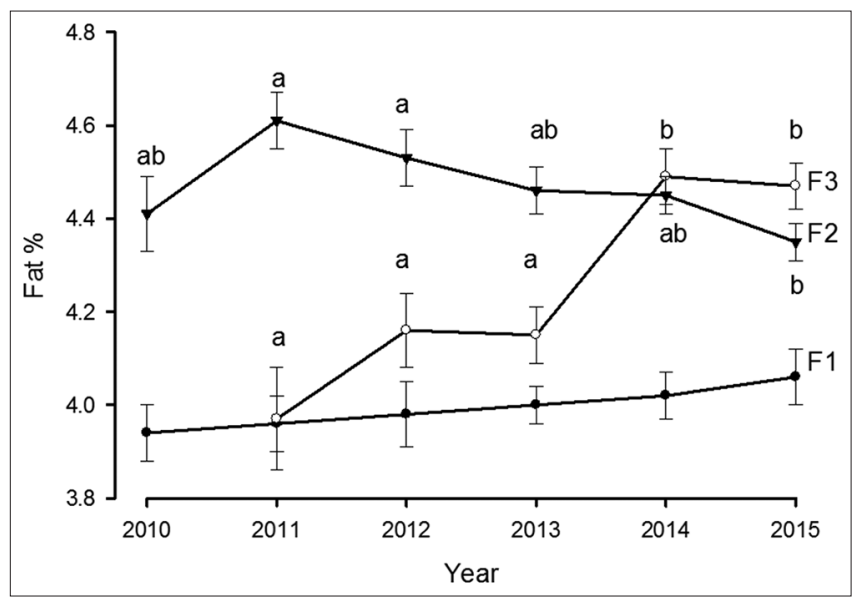

Fig 2. Development of fat $\%$ after using of ML milking system in different breeds from different dairy farms. F1: Farm 1 (Holstein); F2: Farm 2 (Holstein/Red); F3: Farm 3 (Brown Swiss).

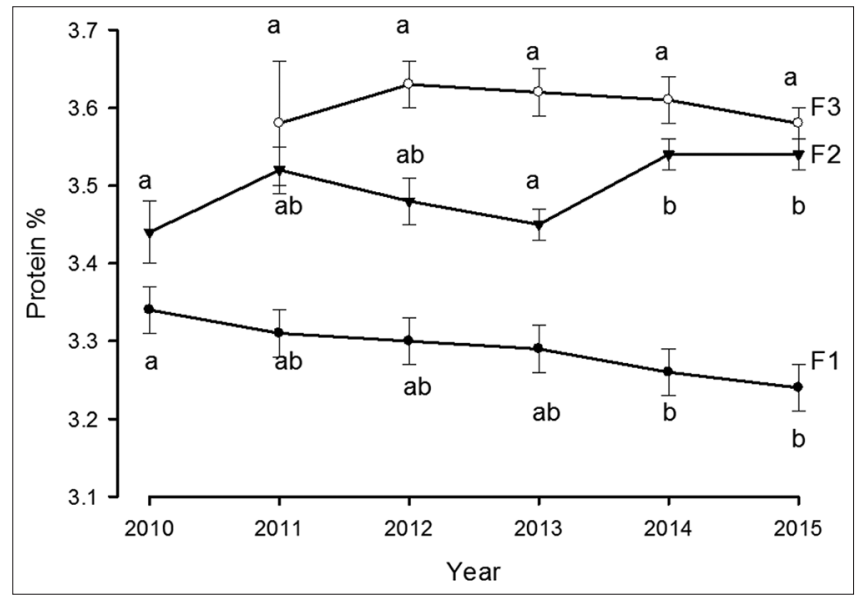

Fig 3. Development of protein \% after the use of ML milking system in different breeds from different dairy farms. F1: Farm 1 (Holstein); F2: Farm 2 (Holstein/Red); F3: Farm 3 (Brown Swiss).

from $20.29 \mathrm{~kg}$ (in 2010) to $28.20 \mathrm{~kg}$ milk/day/animal (in 2012). This represents an increase of $138 \%$. The daily milk 


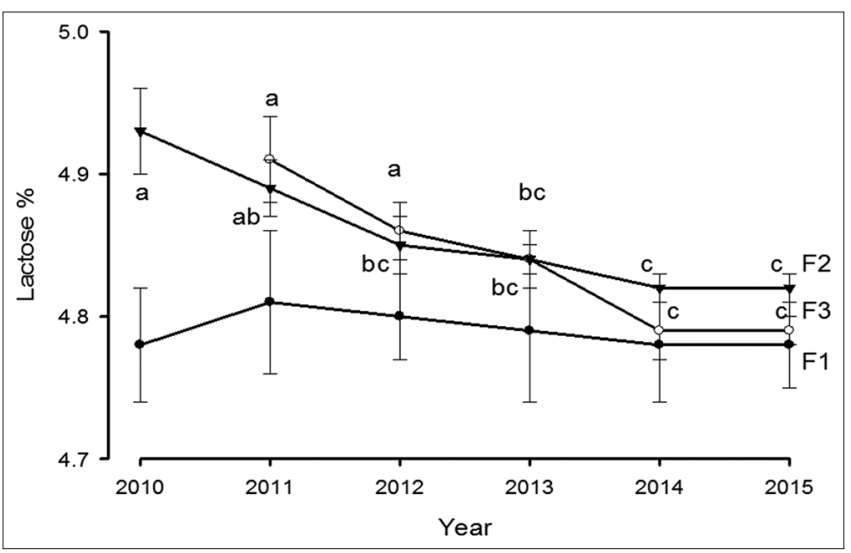

Fig 4. Development of lactose $\%$ after the use of ML milking system in different breeds from different dairy farms. F1: Farm 1 (Holstein); F2: Farm 2 (Holstein/Red); F3: Farm 3 (Brown Swiss).

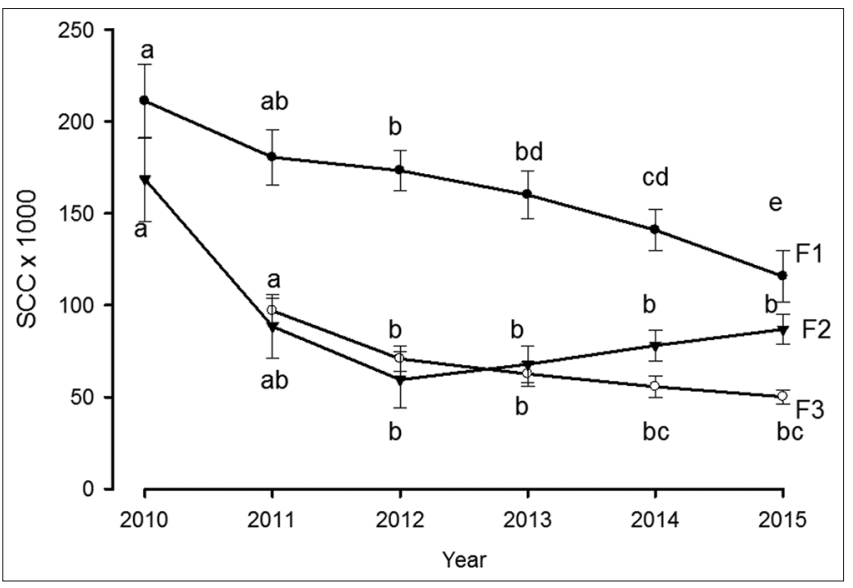

Fig 5. Development of somatic cell count (SCC) $X 10^{3}$ after the use of $\mathrm{ML}$ milking system in different breeds from different dairy farms. F1: Farm 1 (Holstein); F2: Farm 2 (Holstein/Red); F3: Farm 3 (Brown Swiss).

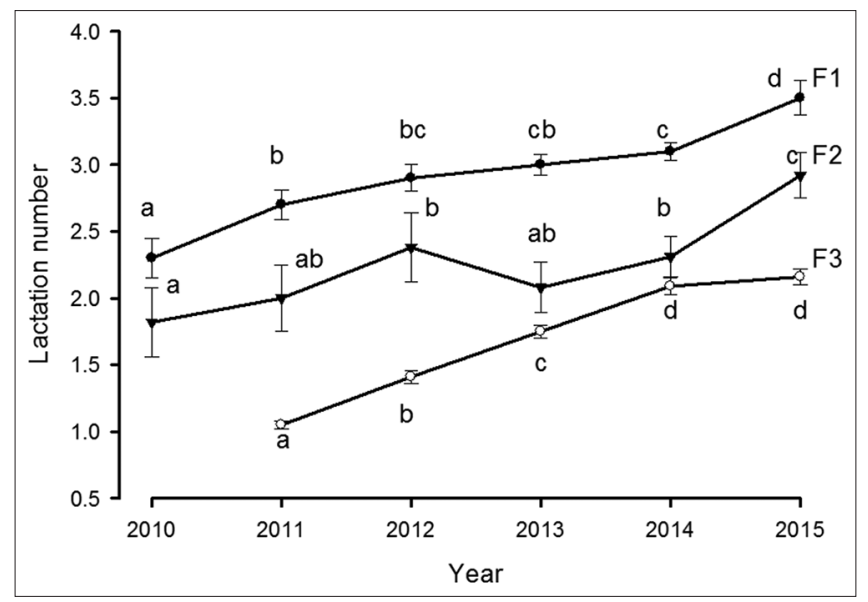

Fig 6. Development of lactation number after the use of ML milking system in different breeds from different dairy farms. F1: Farm 1 (Holstein); F2: Farm 2 (Holstein/Red); F3: Farm 3 (Brown Swiss)

yield then increased constantly until 2015. This signifies an increase in the daily milk yield of $162 \%$ between 2010 and
2015. Similar results also were shown in Farm 3 (Brown Swiss) (Fig. 1) and the daily milk yield has risen from $15.04 \pm 0.83$ (in 2011) to $19.86 \pm 0.67$ (in 2012) kg milk/ animal, which corresponds to an increase to more than $132 \%$. The graph shows the further continuous increase of the daily milk yield until the year 2015 . The daily milk performance has increased to $151 \%$ between 2011 and 2015.

\section{Improvement in milk composition Fat Percentage}

Fig. 2 showed that there were no significant differences $(P>0.05)$ in fat content after using of ML in farm 1 (Holstein Frisian) during the course of the experiment, but fat content came to a slight increase over the course of the experiment and it reached the highest levels in 2015 with $4.06 \pm 0.06 \%$. In Farm 2 (Holstein Frisian/red), the fat content increased slightly from 2010 to 2011 after the changeover to the ML milking system, but no significant difference $(P>0.05)$. Thereafter, the fat content decreased slightly from 2011 to 2014 . Then, it decreased significantly $(P<0.05)$ and reached the output value of $4.35 \pm 0.04 \%$ in 2015.

The fat content of the milk in farm 3 (Brown Swiss) does not show a significant difference $(P>0.05)$ until the year 2013 after the changeover to the ML Milking system in 2011. After that, the fat content rose sharply and significantly $(\mathrm{P}<0.05)$ and it reached the value of $4.49 \pm 0.06 \%$ in 2014 and remaining at this level until 2015.

\section{Protein Percentage}

The statistical analysis shows that the protein content after using of ML in the dairy farm 1 (Holstein Frisian) has no significant differences $(P>0.05)$ in the course of the experiment until 2013. Then, it decreased significantly and reached the value of $3.24 \pm 0.03 \%$ in 2015 as shown in fig. 3 .

In farm 2 (Holstein Frisian/red), the results demonstrated that the protein content did not show any significant difference from 2010 to 2013 ( $P>0.05$ ). The values vary between $3.44 \pm 0.04$ and $3.52 \pm 0.03 \%$. After that, the values rise significantly $(P<0.05)$ and reach $3.54 \pm 0.02 \%$ in 2015 .

In farm 3 (Brown Swiss), other results showed that the protein content of the milk did not change significantly from 2011 to 2015 ( $\mathrm{P}>0.05)$. The values vary between $3.58 \pm 0.08$ and $3.63 \pm 0.03 \%$.

\section{Lactose Percentage}

Fig.4 shows that the lactose content of the milk after application of the ML milking system did not change significantly $(P>0.05)$ in farm 1 and varied between $4.78 \pm 0.03 \%$ and $4.81 \pm 0.05 \%$. It was observed in Farm 2 
that the lactose content did not change significantly from 2010 to 2011. After that, a significant reductions in values of lactose content during the period from 2012 to 2015 were observed $(P<0.05)$ varying between $4.82 \pm 0.01$ and $4.84 \pm 0.01 \%$. In farm 3 , lactose content of the milk did not change significantly $(P>0.05)$ from 2011 to 2013 and after that it was reduced significantly $(P<0.05)$.

\section{Somatic cell count}

The results have shown that the average SCC of milk decreased significantly $(P<0.05)$ in the course of the experiment in dairy farm 1 and reached the lowest values in 2015 with $115.67 \pm 13.90 \times 10^{3}$ cells $/ \mathrm{ml}$. In Farm 2, the SCC of the milk decreased from $168.64 \pm 22.97 \mathrm{X}$ $10^{3}$ cells $/ \mathrm{ml}$ in 2010 to $88.46 \pm 17.15 \times 10^{3}$ cells $/ \mathrm{ml}$ in 2011 , after using ML and reached the lowest values in 2012 with $59.43 \pm 15.09 \times 10^{3}$ cells $/ \mathrm{ml}$. Subsequently, the low level remained until 2015 and the values fluctuated between $67.85 \pm 10.12 \times 10^{3}$ cells $/ \mathrm{ml}$ and $86.92 \pm 8.28 \times 10^{3}$ cells/ $\mathrm{ml}$. In farm 3 , the SCC of milk decreased significantly $(P<0.05)$ from $97.02 \pm 6.70 \times 10^{3}$ cells $/ \mathrm{ml}$ to $70.83 \pm 6.7$ X $10^{3}$ cells $/ \mathrm{ml}$ in 2012 and from 2012 to 2015, the SCC decreased continuously slightly but linearly and reached the lowest values in 2015 with $50.12 \pm 3.70 \times 10^{3}$ cells $/ \mathrm{ml}$ as shown in Fig.5.

\section{Improvement in lactation number}

The results of the research work clearly show that the cows are kept longer in dairy farms 1, 2 and 3. As a result, dairy cows can live longer and bring their genetic potential for the highest milk yield. In farm 1 , the average lactation number of cows increased significantly $(P<0.05)$ from $2.30 \pm 0.15$ in 2010 to 3.50 \pm 0.13 lactations in 2015. In Farm 2, the lactation number of dairy cows has increased significantly $(P<0.05)$ from $1.82 \pm 0.26$ in 2010 to $2.92 \pm 0.17$ in 2015. Thus, the lactation number has been increased by $160.44 \%$. In Farm 3, the statistical analysis has indicated that a clear continuous linear and significant increase in the lactation number of the cows from $1.05 \pm 0.03$ in 2011 to $2.16 \pm 0.06$ in 2015. Thus, the lactation number increases significantly $(\mathrm{P}<0.05)$ to $205.7 \%$ in 2015 as clearly shown in Fig. 6.

\section{DISCUSSION}

Results in Fig. 1, showed the daily milk yield during the study period from 2010 to 2015 increased significantly to $117 \%, 162 \%$ and $151 \%$ in farms 1,2 and 3 respectively. Similar results were established in other studies after using of ML (kaskous, 2014 a, b; Kaskous and Fadlelmoula, 2015; kaskous, 2016).

This shows noticeably the importance of milking system to increase the daily milk production, in addition to other factors which play a crucial role in increasing milk production such as breed, parity, feeding, management and genetic improvement. The feeding and Husbandry conditions in the three farms were excellent before and after using a new milking system. It's known that each breed can produce certain amounts of milk and respond differently to the machine milking (Fazio et al., 2015). For example, a Holstein Friesian cows are capable of higher performance than a brown Swiss. Despite the farms in the study have different husbandry, breeds, management and feeding methods, milk production has increased in these farms after using of ML.

The goal of the milking process is to milk the udders gently, completely and quickly. For this purpose, it is important to prepare the animals optimally before milking. Therefore the stimulation of the udder before milking is required for complete and fast milk removal (Sandrucci et al., 2007). This is shown in the ML milking system, in which it has a special stimulation system.

Studies on the physiological relationships between complete milking and milk secretion rate revealed that the control of milk secretion takes place via local mechanisms in the udder gland tissue. On the basis of the physiological relationships described by Wilde and Peaker (1990), it can be assumed that the epithelial cells milk once again reach the maximum secretion potential after complete removal of the inhibitor or so-called feedback inhibitor of lactation (Wilde and Hurley, 1996; Peaker et al., 1998; Knight et al., 1998). Local control of milk secretion is done by milk removal and the concentration of inhibitor in milk increases as milk accumulates. The secretory rate depends not only upon the concentration of inhibitor in milk but also on efficiency of milk ejection and removal. These factors depend on the technology and technique of milking (Wilde and Peaker, 1990). That means with a correctly specified, installed, operated and maintained milking machine as in ML milking system can promote a high milking performance and better milk contents as well as insure a positive udder health. In the other side, milking process with ML was without stress. Stress is one of the reasons to inhibit milk ejection and if milk ejection is inhibited, inflammation develops in the udder. As a result milk yield and milk quality decreases and SCC increases (Petrovska and Jonkus, 2014).

By a complete stimulation before and during milking with ML, only a small residual milk remains in the udder after milking. This is one of the reasons that milk yield in the farms after using ML milking system continues to become popular. The literatures show that the average residual milk yields about $0.5 \mathrm{~kg}$ per cow per day after two milking times (Burckmaier, 2013). 
The remaining residual milk in the udder after milking has not only an unfavourable effect on milk yield but also affects udder health. Many farmers have noticed that an increase in SCC often leads to acute udder infections when the cows leave the milking parlour with badly milked udders. The reason for this is that residual milk contains nutrients and in the case of infected udders, pathogens and their metabolic products remain in the udders. Despite the technical advances in the milking technique, udder diseases continue to occur very often in many countries of the word (Mrode and Swanson, 1996; Pryce and Brotherstone, 1999; Rupp and Boichard, 1999; Ingvartsen et al., 2003). When the SCC increased, it was seen that milk yield decreased (Petrovska and Jonkus, 2014; Cinar et al., 2015). Due to this fact, it is important to improve the management, husbandry and milking routines, especially the milk removal (RoseMeierhöfer et al., 2010). This can be improved by intensive udder preparation and an optimally adjusted technique.

For all problems mentioned above, the quarter individual milking system ML has been developed.

The use of the new milking system in this study has led to low number of the SCC in the milk on the three farms (Fig. 5). The findings support that since the SCC of the milk in the trial period tended to decline, the reason behind this was due to the ML milking system used, the good hygienic conditions of these farms and there was no stress during and after changeover. On the other hand Rose-Meierhöfer et al. (2014) reported that insufficient preparation of the udder before milking, incorrect vacuum levels; incomplete milking and poor teat condition can adversely affect udder health.

However, ML milking system showed significantly better scores compared to conventional milking system in term of teat colour after milking (Rose-Meierhöfer et al., 2014). This means that the udder remains healthy after milking and the cows remain longer in the farm. As a result, the dairy cows can live longer and bring their genetic potential for the highest milk yield. It's known that the lactation performance of the cow increases with the age up to resulting in high performance (Fahr and Lengerken, 2003; Mellado et al., 2011). This increase can occur up to 4 to 5 lactations (Ray et al., 1992; Mellado et al., 2011). In the present study, the average of lactation numbers during the study period increased from 2.3 to 3.5 , from 1.82 to 2.92 and from 1.05 to 2.16 in the farm 1, 2 and 3 (Fig. 6), respectively. As a result, milk production has continued to rise steadily.

Thus, it can be said that an increase in daily milk yield after using the ML in the examined farms was observed. However, it seems that the changeover of the milking system is linked to the change in the performance- determining factors such as improving the udder health; the dairy cows have remained in the farms. As a result, the cows become older and their performance potential is fully exploited. Thus the milk yield is increased.

Milking machine and milking process have a further important influence on milk fat content (Petrovska and Jonkus, 2014). In the present study with ML milking system the cows in the three farms are milked out completely. As a result the fat content in the milk increases significantly in Farm 1 and 3, resulting in 5 to $13 \%$ more fat in the milk. Thus, if cows are not milked out completely, fat $\%$ will be lower than normal.

However, fat $\%$ was lower in the farm 1 with three milking times per day in comparison with two milking times in the farm 2 and 3. The effect of milking three versus two times a day on milk fat $\%$ has decreased. These results are agreement with Allen et al. (1986) and Gisi et al. (1986). But some researchers have reported that milking twice or thrice a day, shows no change in fat content of the milk (Amos et al., 1985; DePeters et al., 1985). It has also been found that the breed plays a role for the fat content of the milk (Heinrichs et al., 1997; Looper, 2012). In Farm 1, with Holstein breed was shown that fat $\%$ the lowest compared to farm 2 and 3. However, in the farm 2, cows are present with the breed Holstein (red), have shown the best milk fat content compared to Farm 1 and 3.

With regard to milk protein content, the results of this study showed that the milk protein content has increased after application of the ML milking system especially in farm 2. However, this increase in milk protein confirms that the milking process was better with ML Milking system than the old conventional milking system. As shown in Fig.3, the cows in Farm 1 have the lowest milk protein (between 3.24 and 3.30\%) and the cows (Brown Swiss) in Farm 3 have the highest milk protein content (between 3.58 and 3.63\%). In farm 2, the Holstein (red) cows have mean values of protein content (from 3.44 to $3.54 \%$ ) between farm 1 and farm 3 with high tendency to the brown Swiss in the farm 3. These results are consistent with other authors (Linn, 1988; Heinrichs et al., 1997). Breeds differ in milk protein percentage and type of the milk protein produced (Linn, 1988). These results clearly show that the ML milking system has influenced the protein content of the milk in three farms and breeds and the difference in the protein content of the milk between the farms can be attributed to the genetic basis of the breeds.

It is established that the udder health influences the milk protein content (Looper, 2012). Many studies have shown that a negative correlation between SCC in the milk and the milk protein content has been demonstrated (Cinar et al., 
2015). The general effect of mastitis (higher SCC in the milk) is to impair milk synthesis and loosen the connections between cells (Wheelock, 1980). It was observed that SCC had a high significant effect on milk yield, milk protein, milk lactose, total solids (Cinar et al., 2015). However milk proteins synthesized and DNA in the epithelial cells in the udder decrease. Milk from cows with mastitis also showed increased proteolysis activity. Casein hydrolysis begins in the udder between the milking times when subclinical or clinical mastitis is present. By using the ML milking system, the udder health remains stable and consequently more milk and protein is produced in the udder.

Lactose content of milk can be expressed as an average of $4.8 \%$. The variability of the lactose content in the milk is comparatively low, since lactose in milk with mineral substances in the osmotic system is involved. The lactose concentrations in this field studies show normal values (Fig.4). This means that the milk synthesis before the changeover and afterwards well ran. Since the cow tries to keep the lactose content in the milk constant, it is difficult to draw conclusions on the milking process.

\section{CONCLUSION}

The results of the present field study demonstrated that using MultiLactor milking system played an important role in milk performance and milk quality. However, this system can be used in all breeds and farms as well as with 2 or 3 times milking per day. Furthermore, it can be used in carousel or herringbone or tandem milking parlour.

\section{REFERENCES}

Allen, D. B., E. J. DePeters and R. C. Laben. 1986. Three times a day milking: effects on milk production, reproduction efficiency and udder health. J. Dairy Sci. 69: 1441-1446.

Amos, H. E., T. Kiser and M. Loewenstein. 1985. Influence of milking frequency on productive and reproductive efficiencies of dairy cows. J. Dairy Sci. 68: 732-739.

Annen, E. L., R. J. Collier, M. A. McGuire and J. L. Vicini. 2004. Effects of dry period length on milk yield and mammary epithelial cells. J. Dairy Sci. 87: 66-76.

Assan, N. 2014. Significance of litter size, duration of dry period and stage of pregnancy on milk yield and composition in dairy animals. Sci. J. Rev. 3(12): 993-1003.

Behr, B. 2017. Eutergesundheit: So sieht,s in Deutschland aus. Elite Mag. Milcherzeuger 1: 42-44.

Bruckmaier, R. 2013. The Udder of the Modern Dairy Cow Between Evolution and Performance-Oriented Breeding. Workshop on Physiology and Biotechnology of Milk Removal, VeterinaryPhysilogy, Vetsuisse Faculty, University of BERN, Posieux, Switzerland.

Cinar, M., U. Serbester, A. Ceyhan and M. Gorgulu. 2015. Effect of somatic cell count on milk yield and composition of first and second lactation Dairy cows. Ital. J. Anim. Sci. 14(1): 105-108.
Dang, A. K. and S. K. Anand. 2007. Effect of milking systems on the milk somatic cell counts and composition. Livest. Res. Rural Dev. 19(6): 1-8.

DePeters E. J., N. E. Smith and J. Acedo-Rico. 1985. Three or two times daily milking of older cows and first lactation cows for entire lactations. J. Dairy Sci. 68: 123-132.

Dufour, S., A. Frechette, H. W. Barkema, A. Mussell and D. T. Scholl. 2011. Invited review: Effect of udder health management practices on herd somatic cell count. J. Dairy Sci. 94: 563-579.

Fahr, R. D. and G. Lengerken. 2003. Milcherzeugung, GrundlageProzesse-Qualitätssicherung. Deutscher Fachverlag. Germany.

Fazio, E., P. Medica, C. Cravana, and A. Ferlazzo. 2015. Machine milking impact on dairy cows physiological adjustments: an observational approach according to different breed. Acta Sci. Vet. 43: 1265-1273.

Fehlings, K. 2006. Hohe Zellzahlen durch mangelhafte Melktechnik. Top Agrar. 1: 18-20

Gisi, D. D., E. J. DePeters and C. L. Pelissier. 1986. Three times daily milking of cows in California dairy herds. J. Dairy Sci. 69: 863-868.

Heinrichs, J., C. Jones and K. Bailey. 1997. Milk components: Understanding the causes and importance of milk fat and protein variation in your dairy herd. Journal Dairy and Animal Science. Fact Sheet No. 05-97, pp. 1e-8e

Ingvartsen, K. L., R. J. Dewhurst and N. C. Friggens. 2003. On the relationship between lactational performance and health: is it yield or metabolic imbalance that causes diseases in dairy cattle? A position paper. Livest. Prod. Sci. 83: 277-308.

Kanswohl, N., M. Schlegel, J. Burgstaler and D. Wiedow. 2012. Zügig ans schonend melken. Bauernblatt. 40: 39-41.

Kaskous. S. and A. Fadlelmoula. 2015. Adaptability of dairy cows to individual Quarter milking system after changing from tying to loose housing system. Adv. Anim. Vet. Sci. 3(4): 225-232.

Kaskous, S. 2014a. Weniger Zellen mit dem MultiLactor. Elite Mag. Milcherzeuger 1: 41.

Kaskous, S. 2014b. Melken ohne sammelstück, umstellung vom konventionellen auf viertelindividuelles Melken. Agrarmanager. 2: 80-82.

Kaskous, S. 2016. Alte kühe dank neuer melktechnik. Hessens Zukunft. 16(3): 36-39.

Knight, C. H., M. Peaker and C. J. Wilde. 1998. Local control of mammary development and function. Rev. Reprod. 3: 104-112.

Linn, J. G. 1988. Factors affecting the composition of milk from dairy cows. In: Designing Foods: Animal Product Options in the Marketplace, National Research Council, National Academies Press, Washington, DC, pp. 224-241.

Looper, M. 2012. Factors affecting milk composition of lactating cows. Agriculture and Natural Resources. Division of Agriculture Research and Extension University of Arkansas, USA, p. 6.

Marnet, P. G and M. Komara. 2008. Management systems with extended milking intervals in ruminants: Regulation of production and quality of Milk. J. Anim. Sci. 86: 47-56.

Mellado, M., E. Antonio-Chirino, C. Meza-Herrera, F. G. Veliz, J. R. Arevalo, J. Mellado and A. De Santiago. 2011. Effect of lactation number, year, and season of initiation of lactation and treated with recombinant bovine somatotropin. J. Dairy Sci. 94: 45244530.

Mrode, R. A and G. J. T. Swanson. 1996. Genetic and statistical properties of somatic cell count and its suitability as an indirect mean of reducing the incidence of mastitis in dairy cattle. Anim. Breed. Abstr. 64: 847-857. 
Müller, A., S. Rose- Meierhöfer, C. Ammon, S. Elsholz and R. Brunsch. 2011. Comparison of the effects of quarter-individual and conventional milking systems on milkability traits. Arch. Tierzucht. 54(4): 360-373.

Ontsouka, C. E., R. M. Bruckmaier and J. W. Blum. 2003. Fractionized milk composition during removal of colostrums and mature milk. J. Dairy Sci. 86: 2005-2011.

Peaker, M., C. J. Wilde and C. H. Knight. 1998. Local control of the mammary gland. Biochem. Soc. Symp. 63: 71-79.

Petrovska, S and D. Jonkus. 2014. Milking Technology Influence on Dairy Cow Milk Productivity and Quality. 13th International Scientific Conference, Engineering for Rural Development. Proceedings Vol. 13 May 29-30, 2014 Jelgava, Latvia, Ukraine.

Pryce, J. E and S. Brotherstone. 1999. Estimation of lifespan breeding values in the UK and their relationship with health and fertility traits. Interbull Bull. 21: 166-169.

Ray, D. E., T. J. Halbach and D. V. Armstrong. 1992. Season and lactation number effects on milk production and reproduction of dairy cattle in Arizona. J. Dairy Sci. 75: 2976-2983.

Rose-Meierhöfer, S., G. Hoffmann, H. Öz, U. Ströbel and C. Ammon. 2010. Milking-time tests in conventional and quarter-individual milking systems. Agric. Forestry Res. 1(60): 11-16.
Rose-Meierhöfer, S., A. B. Müller, L. Mittmann, S. Demba, A. C. H. Entorf, G. Hoffmann, C. Ammon, H. J. Rudovesky and R. Brunsch. 2014. Effects of quarter individual and conventional milking systems on teat condition. Prev. Vet. Med. 113: 556-564.

Rupp, R and D. Biochard. 1999. Genetic parameter for clinical mastitis, somatic cell score, production, udder type traits, and milking ease in first lactation Holsteins. J. Dairy Sci. 82: 21982204.

Sandrucci, A., A. Tamburini, L. Bava and M. Zucali. 2007. Factors affecting milk flow traits in dairy cows: Results of a field study. J. Dairy Sci. 90: 1159-1167.

SAS. 1999. Institute, Version 8, Cary NC, USA.

Tancin, V., A. H. Ipema, P. Hogewerf and J. Macuhova. 2006. Sources of variation in milk flow characteristics at udder and quarter levels. J. Dairy Sci. 89: 978-988.

Wheelock, J. V. 1980. Influence of physiological factors on the yields and contents of milk constituents. Bull. Int. Dairy Fed. 125: 83-87.

Wilde, C. J and W. L. Hurley. 1996. Animal models for the study of milk secretion. J. Mammary Gland Biol. Neoplasia. 1: 123-134.

Wilde, C. J and M. Peaker. 1990. Autocrine control in milk secretion. J. Agric. Sci. 114: 235-238. 